\title{
A Vector Autoregression Analysis of Foreign Direct Investment and Its Link to Competitiveness
}

\section{- Marinko Skare, Dajana Cvek}

\begin{abstract}
This study has investigated the impact of foreign investments on competitiveness in Croatia in terms of macroeconomic stability conditions using data from 2002 to 2017. In this paper, we focus on the relationship between critical macroeconomic indicators and foreign direct investments (FDI) as a growth and competitiveness driving factor. To study the impact of FDI on competitiveness levels in Croatia, time series methods are used. Macroeconomic stability is a necessary but not sufficient condition for economic competitiveness. FDI can increase the level of economy's competitiveness, although the total effect depends on the FDI structure (greenfield vs brownfield). The vector auto-regression (VAR) model and Granger causality have identified a decrease in FDI inflows in the recession period. There is a correlation between FDI, employment, GDP and exports. The goal of our study is to investigate the impact of FDI on macroeconomic indicators, FDI inflow determinants, and their impact on the overall competitiveness and growth. In this study, we identify and explain the positive and negative effects of FDI setting the framework for efficient macroeconomic policy. The results should serve policymakers in efforts to improve decisions that affect the country's macroeconomic competitiveness. Significant differences were demonstrated in Croatia's macroeconomic performance over the observed period. Our results show FDI as a potential inefficiency growth factor among selected indicators if it is not controlled in terms of investment structures and funding sources. The country's competitiveness depends on stock investment, but even more on the structure of the FDI flowing in the economy.
\end{abstract}

Keywords: foreign direct investments, vector autoregression, competitiveness, economic growth, macroeconomic policy

JEL Classification: E2, F21, O16, P33

Received: July, 2020

1st Revision: October, 2020

Accepted: October, 2020

\section{INTRODUCTION}

Foreign direct investments are a necessary but not sufficient precondition for economic growth (Babić et al., 2001; Bilas \& Franc, 2006; Dritsaki, \& Stiakakis, 2014). A large body of literature locates a positive link between the level of FDI flowing to the country and achieved economic growth. At the same time, these studies have not considered a third factor which influences all 
the model. That factor is the structure of the FDI or greenfield vs brownfield investments. The overall impact of FDI on a country's economic growth in the end depends on the structure of FDI, not on the total level (the stock value of FDI). We provide empirical results for our hypothesis using data for Croatia, a country that during its transition to a single nation and EU member attracted a considerable amount of FDI, yet achieved only modest economic growth and lagged behind other EU members. Although Croatia did attract a sufficient level of FDI, the majority of the investments were brownfield investments. High labor costs and a disincentive tax policy (a policy which negatively affects competitiveness) resulted in low rates of return of investments, leading to mainly brownfield investments. Low rates of return of investments caused by taxation as well as mainly brownfield investments clustered in few sectors (telecommunications, trade and financial services, tourism) played a growth-constraining role in Croatia.

Foreign direct investment (FDI) refers to investments by foreign legal and natural persons in the economic activities of a country and is considered to be long-term investment (Gavurova et al., 2019). These investments are realized through the establishment of a company abroad (a subsidiary, a representative office or an independent company), and by purchasing at least $10 \%$ of a foreign company, investment can be forwarded to enable participation in the company's management. Foreign direct investment to extractive sectors for the use of domestic resources and supply to the domestic market, then to export sectors, aims to reduce the indebtedness of each country. In terms of economics globally, FDIs have had many positive effects, as this investment contributes to the growth of competitiveness, employment, and international trade. Focus is thus placed on economic growth and development. Foreign direct investment can be categorized in various ways, e. g. by type of investment: greenfield investments, brownfield investments, cross-border acquisitions, cross-border mergers, and joint ventures. Foreign direct investment encourages economic growth through the accumulation of capital in the recipient country for new resources and technologies as well as increasing and enhancing human capital. These investments also have a significant impact on the recipient country's global competitiveness. Taxation plays a significant role in the attraction of FDI, thus alleviating tax competition (reducing fiscal pressure) has a significant impact on production, investments, and competitiveness (Paun, 2019; Dobrovič et al., 2018). For the CEE countries, Chinese foreign direct investments have had a significant impact on the competitiveness of countries in the Western Balkans (Jacimovic, 2018).

The benefits of foreign direct investment can be divided into several clusters. Technologically advanced companies have the advantage of competing in foreign markets on a global level. They also stimulate export employment, in that capital inflows and new technological ideas come into play. Other benefits include the development of specialized skillsets, growth boosts, productivity, as well as enhancing an overall better knowledge of the local market (Bilan et al., 2017). Dvorský et al. (2020) argued that proper strategic management improves the competitive ability of the company and its stability in domestic and foreign markets.

The scientific contribution of this paper is in the consideration of particular aspects of Croatia's macroeconomic performance with an emphasis on the relationship between key macroeconomic indicators, competitiveness, and FDI. We present an empirical analysis of the impact of selected indicators on Croatia's macroeconomic performance and competitiveness, filling the research gap in terms of why FDIs have shown a neutral or negative effect in some countries. 
The goal of our study is to demonstrate why FDI has not had a significant impact on the competitiveness of the Croatian economy, as would be expected in theory. Institutional factors and other micro determinants (enterprise sector structure, low share of the (IT) industry, the sub-optimal structure of investments) have significantly affected the country's competitiveness. Our study results are in line with the results of Kersan-Škabić \& Zubin (2009), who found that FDI inflow has no impact on the GDP growth and export, while it does harms employment. Our findings are also in concordance with the results of similar studies (Rabar \& Cvek, 2019).

Croatia's economic competitiveness is low compared to other transitional countries. This is a consequence of inefficient transitional reforms (privatization) and institutional factors, with FDI results showing the side-effects of the unproductive growth model in Croatia. Our paper provides empirical evidence that FDI is necessary but not sufficient to increase competitiveness and change the economic growth model in Croatia.

Our article is structured as follows: after the introduction to the link between FDI and economic growth (competitiveness), the currently existing body of literature in the field is reviewed. In section three, the data and the methodological framework of the study are described. The next section discusses the results and practical implications of the study by concluding the remarks in section five.

\section{THEORETICAL BACKGROUND}

Horizontal investments arise to avoid the payment of duties, with trade and direct investments serving the domestic market (substitutes); thus trade liberalization should have the effect of reducing foreign direct investment (Kersan-Škabić, 2017; Bilan et al., 2019). Horizontal investments are most often undertaken because of market expansion, while vertical investments are mostly undertaken to reduce production costs. In doing so, horizontal investments are a substitute for trade and are undertaken when the cost of trade in the final product is high, while vertical investments are made when trade costs are low, with verticality contributing to the development of trade relations between countries (Pavlović, 2008; Bobenič Hintošová et al., 2018).

Vertical investments occur due to the geographical separation of business activities, according to the stages of the production process. This type of investment is most often the result of a search for cheaper resources or attempts to benefit from the comparative advantages of certain locations. They entail the cheaper procurement of raw materials and a closer relationship with customers in foreign markets through the acquisition of distribution centers and the stimulation of innovation. Simply, these investments occur when foreign companies cannot reap the benefits of their investment in other ways.

The important determinants of a country's attractiveness to foreign investors are good basic infrastructure, connectivity of the economy with other countries, political stability and favorable legislation of the country, the stability of the tax system, as well as incentive measures. For transitional countries such as Croatia, investments are intensely focused on the service and financial sectors along with the recapitalization of banks in foreign ownership. Seeking to optimize the portfolio of a foreign company, a multinational company will focus on maximizing profits, which will give it a higher rate of return with a lower risk rate. For example, if a lower 
rate of return is expected in a particular country, a higher rate of return abroad may motivate foreign investors. The theory is also relevant of industrial organization. The expected yield from an FDI affiliate is higher than the yield of a licensed domestic company because of its proximity to the market, lower labor costs, conquering local markets. FDI can also serve strategic goals such as easier accessibility to the recipient country, access to raw materials, technology, and cheaper labor, and to replace exports (Belullo, 2009, 2011; Cieślik \& Hien Tran, 2019). Blažková \& Dvouletý (2018) show firm-level determinants of profitability of companies in the business environment of country correlate with market share (also a positive effect to foreign investors).

FDIs are, therefore, necessary but not a sufficient factor of development in the Western Balkan region (Popović \& Erić, 2018). Shohinger et al. (2006) start from the theory that FDIs are essential for the competitiveness of the economy by applying adequate fiscal and monetary policies. Škuflić \& Botrić (2009) start from the theory that FDI plays a vital role in the Croatian economy and that export orientation, level of education and domestic investments in the country are essential for attracting them. Klapić \& Nuhanović (2011) represent factors affecting the FDI flow, market, quality of human resources, the legal framework for economic activity, development of the financial sector, macroeconomic stability, and privatization of state capital. In the context of macroeconomic stability, the authors showed a positive impact of the management of market risk sources on business entities in service companies (Khan et al., 2019) and generally in the segment of SMEs (Dvorský et al., 2019) in the Czech Republic.

The downside is that foreign investment is more expensive because it requires a higher amount of funds, higher costs and the risk of investing when deciding. Attention should be paid to the planning timeframe, which is longer due to the risk, the right strategies and decisions need to be made, and the political situation of the recipient country needs to be made aware. Croatia has attracted a high stock of foreign direct investment and relatively stands out as the country with the most considerable amount of foreign direct investment in terms of the size of its economy but is concerned by their sectoral orientation. The activities that have attracted the most foreign direct investment are financial intermediation, chemical and chemical product manufacturing, telecommunications, trade, and the oil industry. The expected effects of investment, such as an increase in exports, reduction in unemployment, and increasing competitiveness depend on the initial conditions of the receiving country, its economic policy, its education on the workforce, and the level of technological development.

\section{RESEARCH OBJECTIVE, METHODOLOGY AND DATA}

The aim of this study is to analyze the importance of FDI and its impact on economic growth and competitiveness with particular reference to the Croatian economy. The authors explore how FDI affects the competitiveness of the Republic of Croatia, its impact on exports, employment, gross domestic product (GDP), and the overall competitiveness between 2002 and 2017. The study also explores and discover the FDI flows and the main constrains and their indirect effects on economy's competitiveness. The hypothesis is that FDI in Croatia had a minor impact on competitiveness since majority of FDI were Brownfield investments.

Our study goal is to show the FDI is necessary but not sufficient precondition for country's 
economic growth. The structure of FDI is the element that in the end defines the overall results of FDI on economic growth. To study the impact of FDI on country's growth, Croatia is used as a key study since the overall structure of the FDI flowing to Croatia consisted of brownfield investments to the financial and service sectors, mainly mortgage markets.

The FDI impact period on GDP as an overall competitiveness proxy, employment (EMP), exports (EXP) extend from the second quarter (2002:2) to the third quarter (2017:3). Data from the Eurostat database is used, while FDI is from the Croatian national bank (CNB) statistical database.

For the export variable, we assumed real exports $(2010=100)$ of goods and services, seasonally and calendar adjusted, for the foreign direct investment indicator FDI of foreign direct investment from all countries, in millions of euros, for the employment indicator total employed in thousands from 20 to 64, seasonally adjusted, and for the GDP indicator real GDP $(2010=100)$, also seasonally adjusted. We consider real GDP to be a better indicator as prices fluctuate over a period of time, thus eliminating the impact of price movements from nominal GDP (by deflating nominal GDP).

We modeled the period by one dummy recession variable from 2009: 1 to 2014: 1 We take the logarithm, seasonally adjusted by the Gretl software package (ARIMA X12), to get a constant elasticity expressed in relative changes (\%).

As stationarity is an assumption based on statistical procedures used in the analysis of time series or series, non-stationary data is often transformed to become stationary and valid for further analysis (Belullo, 2009, 2011).

After testing for stationarity, we test for cointegration using Johansen (1991, 1995). Since our sample has non-stationary data with no cointegration links (test results not presented due to space constraints) to estimate the model, we processed using a standard VAR model.

Processes with one or more root units can be stationed through differentiation. Augmented Dickey-Fuller (ADF) following (Fuller, 1996) statistics used in the test are negative numbers, the smaller the number, the stronger the rejection of the hypothesis that there is a unit root at some level of reliability. We display the ADF test results in Table 1.

Tab. 1 - Results of the ADF test. Source: own research

\begin{tabular}{|l|l|l|l|l|}
\hline VARIABLE & \multicolumn{2}{|l|}{ STATIONARY TEST } & \multicolumn{2}{l|}{ VARIABLE } \\
\hline & With constant & $\begin{array}{l}\text { With constant/ } \\
\text { trend }\end{array}$ & & With constant \\
\hline 1_FDI & $-5.91 *$ & $-5.92^{*}$ & d_1_FDI & $-6.68^{*}$ \\
\hline 1_EMP & -1.65 & -1.54 & d_1_EMP & $-6.96^{*}$ \\
\hline 1_EXP & -1.32 & -1.38 & d_1_EXP & $-8.29^{*}$ \\
\hline I_GDP & -2.54 & -1.09 & d_1_GDP & $-6.56^{*}$ \\
\hline
\end{tabular}

Notes: one-star $\left(^{*}\right)$ if statistically significant at the significance level of $10 \%$ (p-value $\left.<0.1\right)$, two-star $(* *)$ if statistically significant at the significance level of $5 \%$ (p-value $<0.05)$, or three-star $(* * *)$ if statistically significant at the significance level of $1 \%$ (p-value $<0.01)$. 
From Table 1, we can see series are difference stationary for foreign direct investments, employment, export, and GDP. Therefore, we proceed with the lag selection for the VAR model (see Table 2).

Tab. 2 - Lag selection in VAR. Source: own research

\begin{tabular}{|l|l|l|l|l|l|}
\hline Lags & LogL & LR & AIC & BIC & HQC \\
\hline 1 & 419.45158 & & $-14.646355^{*}$ & $-13.762362^{*}$ & $-14.305433^{*}$ \\
\hline 2 & 429.37733 & 0.22698 & -14.421383 & -12.948061 & -13.853180 \\
\hline 3 & 446.97610 & 0.00373 & -14.480596 & -12.417946 & -13.685113 \\
\hline 4 & 456.80270 & 0.23625 & -14.251952 & -11.599973 & -13.229187 \\
\hline 5 & 471.44979 & 0.02203 & -14.201844 & -10.960537 & -12.951799 \\
\hline 6 & 485.29012 & 0.03451 & -14.121856 & -10.291220 & -12.644530 \\
\hline 7 & 507.65076 & 0.00015 & -14.357436 & -9.937471 & -12.652829 \\
\hline 8 & 524.21890 & 0.00709 & -14.378478 & -9.369185 & -12.446590 \\
\hline
\end{tabular}

Notes: LR (sequential modified LR test statistics at 5\% level), AIC = Akaike information criterion, SC $=$ Schwarz information criterion, HQ = Hannan-Quinn information criterion.

After stationing the differentiated series, it is necessary to determine the time shifts before constructing the VAR model itself to get the optimal number of shifts that will be of importance to us for further analysis. The length of the lag can be determined using a selection criterion model, and the value $\mathrm{p}$ that minimizes one of the criterion models is used. The goal is to minimize statistics to get optimal time offsets through the Akaike Information Criterion (AIC), Schwartz, or Schwartz-Bayes Criteria (SC, SBC) and Hannan-Quinn (HQIC) criteria. The HQ criterion will test the number of time shifts on which its dynamics depend. Based on the lag selection test results from Table 2, we set up a VAR (1) model of the form

$\mathrm{x}_{\mathrm{t}, 1}=\alpha_{1}+\phi_{11} \mathrm{x}_{\mathrm{t}-1,1}+\phi_{12} \mathrm{x}_{\mathrm{t}-1,2}+\phi_{13} \mathrm{x}_{\mathrm{t}-1,3}+\phi_{14} \mathrm{x}_{\mathrm{t}-1,4}+\phi_{15} \mathrm{D}_{\mathrm{t}-1,5}+\mathrm{w}_{\mathrm{t}, 1}$

$\mathrm{x}_{\mathrm{t}, 2}=\alpha_{2}+\phi_{21} \mathrm{x}_{\mathrm{t}-1,1}+\phi_{22} \mathrm{x}_{\mathrm{t}-1,2}+\phi_{23} \mathrm{x}_{\mathrm{t}-1,3}+\phi_{24} \mathrm{x}_{\mathrm{t}-1,4}+\phi_{25} \mathrm{D}_{\mathrm{t}-2,5}+\mathrm{w}_{\mathrm{t}, 2}$

$\mathrm{x}_{\mathrm{t}, 3}=\alpha_{3}+\phi_{31} \mathrm{x}_{\mathrm{t}-1,1}+\phi_{32} \mathrm{x}_{\mathrm{t}-1,2}+\phi_{33} \mathrm{x}_{\mathrm{t}-1,3}+\phi_{34} \mathrm{x}_{\mathrm{t}-1,4}+\phi_{35} \mathrm{D}_{\mathrm{t}-3,5}+\mathrm{w}_{\mathrm{t}, 3}$

$\mathrm{x}_{\mathrm{t}, 4}=\alpha_{4}+\phi_{41} \mathrm{x}_{\mathrm{t}-1,1}+\phi_{42} \mathrm{x}_{\mathrm{t}-1,2}+\phi_{43} \mathrm{x}_{\mathrm{t}-1,3}+\phi_{44} \mathrm{x}_{\mathrm{t}-1,4}+\phi_{45} \mathrm{D}_{\mathrm{t}-4,5}+\mathrm{w}_{\mathrm{t}, 4}$

with foreign direct investments (FDI), exports (EXP), employment (EMP), and competitiveness (GDP) as variables in the $\operatorname{VAR}(1)$ model. We use exogenous recession dummy variable (D) to address the effects of the 2008 financial crisis.

\section{RESULTS AND DISCUSSION}

In this section, we present the VAR analysis results between foreign direct investment and economic growth (competitiveness) in Croatia from 2002 to 2017.

Variables of GDP, exports, and employment follow a trend. We test such processes for stationarity using the Dickey-Fuller test. If we can reject the hypothesis with 5\% significance or $95 \%$ confidence, it means that the trend is deterministically significant; the trend stems from a constant 
member and unit root of the process itself. To deal with stationarity, we transform the variables using the differencing procedure.

VAR model results with the Granger causality test is presented in Table 3.

Tab. 3 - VAR foreign direct model with FDI as dependent variable. Source: own research

\begin{tabular}{|l|l|l|l|l|}
\hline Constant & Coefficient & Std.error & t-ratio & p-value \\
\hline const & -34.942 & 18.069 & -1.934 & 0.058 \\
\hline 1_FDI_1 & -0.026 & 0.131 & -0.197 & 0.844 \\
\hline 1_EXP & -9.063 & 5.956 & -1.522 & 0.134 \\
\hline 1_GDP & 9.122 & 6.495 & 1.404 & 0.166 \\
\hline 1_EMP & 5.601 & 2.822 & 1.985 & $0.052^{*}$ \\
\hline recession & -0.765 & 0.247 & -3.100 & $0.003^{* * *}$ \\
\hline R $^{2}$ & 0.300393 & Adjusted R ${ }^{2}$ & 0.236792 & \\
\hline F(5,55) & 4.723106 & P-value(F) & 0.001165 & \\
\hline Durbin-Watson & 1.830602 & & & \\
\hline
\end{tabular}

Notes: one-star $\left(^{*}\right)$ if statistically significant at the significance level of $10 \%$ (p-value $<0.1$ ), two-star $(* *)$ if statistically significant at the significance level of $5 \%$ (p-value $<0.05$ ), or three-star $(* * *)$ if statistically significant at the significance level of $1 \%$ ( $\mathrm{p}$-value $<0.01$ ).

From the results obtained, we can see that the independent variables do not affect FDI in the Granger sense, whereas the dummy variable recession has a significant influence on a decrease in the FDI inflows in the recession period. Employment conditions are important (supply of labor and labor markets elasticities) in driving FDI to the country. Recession shows to have significant adverse effects on FDI in Croatia.

With the integration of the Republic of Croatia into the European Union, more capital inflows and investments of foreign countries into Croatia than ever before were expected. However, that was not the case. The authorities in the Republic of Croatia must know the importance of directing efforts to attract FDI. From 2001 to 2007, due to fiscal consolidation, the share of public spending decreased from $22.9 \%$ (2001) to $20.1 \%$ of GDP (2007). The war period demotivated potential investors. By 2001, the share of investments is increasing to approx. $23 \%$ because of investments in infrastructure, road construction, and construction. A high investment rate of an average of over 30\% of GDP was recorded in 2005-2007. Between 2002 and 2017, most foreign investments came from Austria, Germany, and the United States.

In comparison with other transitional countries, Croatia has attracted a level of foreign investment during this period which could be said to be above average, satisfactory. What all these companies see as an advantage is the location of Croatia, given that it represents the door to EU integration, and is close to developing countries in Eastern Europe. Croatia has attracted around 20 billion euros in foreign direct investment. Over 15,000 foreign companies have invested in the Republic of Croatia or have chosen it as the location for the business of their economic entity. Of this, we have realized approximately 6 billion since Croatia was in the European Union. The biggest problem for Croatia is that from the beginning of foreign investments until today, there 
are no greenfield investments. The investments made so far mainly relate to decisions on privatization in the acquisition of ownership shares in the state-owned economic entities. The proceeds from the sale of equities were mostly spent on closing budget deficits, so we could say the state is stuck in a loop since there are no significant greenfield investments.

Tab. 4 - VAR foreign direct model with EXP as dependent variable. Source: own research

\begin{tabular}{|l|l|l|l|c|}
\hline Constant & Coefficient & Std.error & t-ratio & p-value \\
\hline const & 0.106 & 0.389 & 0.271 & 0.787 \\
\hline 1_FDI_1 & -0.001 & 0.003 & -0.277 & 0.782 \\
\hline 1_EXP & 0.586 & 0.128 & 4.574 & $0.000 * * *$ \\
\hline 1_GDP & 0.422 & 0.140 & 3.019 & $0.004 * * *$ \\
\hline 1_EMP & -0.016 & 0.061 & -0.262 & 0.794 \\
\hline recession & -0.008 & 0.005 & -1.584 & 0.119 \\
\hline $\mathrm{R}^{2}$ & 0.978980 & Adjusted R2 & 0.997069 & \\
\hline $\mathrm{F}(5,55)$ & 512.3063 & P-value(F) & 0.0000 & \\
\hline Durbin-Watson & 2.035104 & & & \\
\hline
\end{tabular}

Notes: one-star $\left(^{*}\right)$ if statistically significant at the significance level of $10 \%$ (p-value $\left.<0.1\right)$, two-star (**) if statistically significant at the significance level of $5 \%$ (p-value $<0.05)$, or three-star $(* * *)$ if statistically significant at the significance level of $1 \%(\mathrm{p}$-value $<0.01)$.

In terms of exports of high technology, Croatia is lagging behind the world and the European average. On one hand, it uses a high level of technology. For example, with developed telecommunications and information structures, it is a small producer and exporter of high-technology products. For consumers, the situation is optimistic regarding the reduction of net taxes, the increase in transfers, the reduction of autonomous taxes, the increase in employment, which at the same time leads to positive expectations of future income and higher personal consumption in the long run. Since Croatia is an import-dependent country, increased value-added production increases exports (Table 4).

Croatia had an average annual GDP growth of $4 \%$ by 2008 , and there had also been a decrease in the foreign trade deficit, slower growth in foreign debt, and price stability resulting from the new political reform. The country has made a significant fiscal inflow by increasing its production and income from tourism, being more competitive in the world market, and becoming a full member of world associations.

Tab. 5 - VAR foreign direct model with EMP as dependent variable. Source: own research

\begin{tabular}{|l|l|l|l|l|}
\hline Constant & Coefficient & Std.error & t-ratio & p-value \\
\hline const & 0.6889 & 0.3989 & 1.727 & $0.0898^{*}$ \\
\hline 1_FDI_1 & 0.0046 & 0.0029 & 1.605 & 0.1142 \\
\hline 1_EXP & -0.0486 & 0.1314 & -0.369 & 0.7130 \\
\hline 1_GDP & 0.0725 & 0.1433 & 0.506 & 0.6148 \\
\hline 1_EMP & 0.8886 & 0.0623 & 14.260 & $0.000^{* * *}$ \\
\hline
\end{tabular}




\begin{tabular}{|l|l|l|l|l|}
\hline recession & -0.0085 & 0.0054 & -1.574 & 0.1212 \\
\hline $\mathrm{R}^{2}$ & 0.901583 & Adjusted R2 & 0.892636 & \\
\hline $\mathrm{F}(5,55)$ & 100.7695 & P-value(F) & 0.0000 & \\
\hline Durbin-Watson & 1.901243 & & & \\
\hline
\end{tabular}

Notes: one-star $\left(^{*}\right)$ if statistically significant at the significance level of $10 \%$ (p-value $<0.1$ ), two-star $(* *)$ if statistically significant at the significance level of $5 \%(\mathrm{p}$-value $<0.05)$, or three-star $(* * *)$ if statistically significant at the significance level of $1 \%$ ( $\mathrm{p}$-value $<0.01)$.

We can further conclude that there is a causal link between employment, GDP and exports. The economic growth in Croatia is mainly caused by cyclical developments in the economy (changes in monetary policies) rather than structural changes in the economy (transition, globalization, and integration), see Škare (2014). After the war period, Croatia moved to the so-called "secondary stages of transition" to join the European Union. Croatia signed the Accession Agreement in October 2005, starting the first negotiations.

Fiscal policy restriction refers to the position of a country that it has against the entire population, for example, fiscal and monetary policy mismatches, poor budgetary planning, the lack of spending and the structure of public expenditures, as well as inadequate deficit financing. In such situations, we should pursue fiscal and monetary policy combinations to preserve price stability and the stability of the domestic currency, achieving growth and high employment. Besides all these facts, we can say that fiscal policy is also included in development policies addressing strategic goals, including an international balance of payments, uniformity of regional development, rising living standards, socially income redistribution. Macroeconomic policy and privatization delaying the implementation of structural reforms in Croatia are the main culprits of today's unemployment rate. They reflect the consequence of such an economic policy in the excessive number of retired persons demanding significant financial resources, and the Pension and Disability Insurance Fund does not have that many resources at its disposal to solve their problem. In these circumstances, there has been an unsustainable expansion of public spending, which is financed mainly through the taxation of entrepreneurs, causing high labor costs, which hinders employment growth. Unemployment can be solved by reducing labor costs only, reducing the marginal cost of hiring additional workers (Škare, 2001).

Tab. 6 - VAR foreign direct model with GDP as dependent variable. Source: own research

\begin{tabular}{|l|l|l|l|l|}
\hline Constant & Coefficient & Std.error & t-ratio & p-value \\
\hline const & -0.491 & 0.252 & -1.943 & $0.057^{*}$ \\
\hline 1_FDI_1 & -0.000 & 0.002 & -0.121 & 0.904 \\
\hline 1_EXP & 0.053 & 0.083 & 0.640 & 0.524 \\
\hline 1_GDP & 0.904 & 0.091 & 9.967 & $0.000^{* * *}$ \\
\hline 1_EMP & 0.094 & 0.039 & 2.381 & $0.021^{* *}$ \\
\hline recession & -0.007 & 0.003 & -1.963 & $0.055^{*}$ \\
\hline $\mathrm{R}^{2}$ & 0.990535 & Adjusted R & 0.989675 & \\
\hline $\mathrm{F}(5,55)$ & 1151.199 & P-value(F) & 0.0000 & \\
\hline
\end{tabular}




\begin{tabular}{|l|l|l|l|l|}
\hline $\begin{array}{l}\text { Durbin- } \\
\text { Watson }\end{array}$ & 1.958013 & & & \\
\hline
\end{tabular}

Notes: one-star $\left(^{*}\right)$ if statistically significant at the significance level of $10 \%$ (p-value $\left.<0.1\right)$, two-star (**) if statistically significant at the significance level of $5 \%$ (p-value $<0.05)$, or three-star $(* * *)$ if statistically significant at the significance level of $1 \%$ (p-value $<0.01)$.

Table 6 shows the impact of FDI, EXP, EMP and the 2008 recession on Croatia competitiveness measured by the GDP change. We observe that FDI did not increase the country's competitiveness. To the contrary, in fact, it was decreased due to the FDI structure and non-transparent privatization from the start since 1990. Multicollinearity test results do now show the presence of multicollinearity in the model (test results not presented here due to publishing space constraints).

The entry of foreign capital into the country increases marginal labor productivity. This gives room for increasing profits but also for raising real wages in the long run. The main cause of foreign direct investment deficiency in Croatia is privatization. In this way, there has been no investment in recent production, namely greenfield investments. Brownfield investments aim to make the company more profitable, and the easiest way is to raise their productivity by reducing the number of employees. It is noticeable that over the years, public expenditures have been steadily increasing, causing GDP to decline. The government is more focused on tax increase and budget deficit disregarding development goals, such as overvalued investments in roads, highways, hotels and accommodation units (which is understandable on one hand, since Croatia is a Mediterranean country investing in tourism development). We face scarce financing for boosting industrial production and entrepreneurship, especially when one wants to start a business, and the entrepreneur faces the dilemma of administrative paperwork and high taxes. Fiscal and monetary policy must determine whether long-term or short-term economic goals are to be achieved. The short-term goals are those that focus on current economic developments, with long-term ones aiming for a sustainable GDP rate. Looking at Croatia, fiscal policy should help stimulate economic growth and development as well as intervene in the redistribution of income, while a more flexible policy in the form of tax cuts would lead to more lucrative investment. Also, according to all reports, the level of corruption is very high, with all these indicators working against an easy and effective start-up climate, especially when it comes to long-term survival. The procedure for starting a business is extremely complicated, which is another reason there are not as many greenfield investments. Croatia was attractive to a high level of investors and stood out as the country with the greatest relative amount of FDI in terms of size of the economy, although their sectoral focus works against the country.

The expected effects of investment increase on exports, e. g. a reduction in unemployment, depends on the initial conditions of the receiving country, its economic policy, the education of the workforce, and the level of technological development. These preconditions have been partially created, but there are some which still need to be worked on, are, for example, firm support from the government of the Republic of Croatia in encouraging new investments. Also, agencies such as the Investment and Competitiveness Agency and the Export and Investment Promotion Agency have been established. In the first six months of 2006, the Export and Investment Promotion Agency helped launch investment projects worth 260 million EUR. The principal 
purpose of this agency is to build a positive image of the Republic of Croatia in the world, to represent the Republic of Croatia as an excellent potential investment destination which provides services to potential investors. What is essential is to change the investment climate in Croatia, as with the current investment climate, investors do not seem particularly interested. Since the establishment of the Foreign Investment Attraction Agency, Croatia has not again had a strategy for attracting foreign investment. Institutional and political obstacles include an ineffective judiciary, the relativization of obligations, and ineffectiveness of ownership determination services. One problem is the constant change of the legislative framework, with such fluctuation not having a positive effect on foreign investors. All investors seek a stable, stimulating work environment, which Croatia has failed to consistently provide all these years. The procedure for starting a business is extremely complicated, which is why there are not as many greenfield investments. Also, according to all reports the level of corruption is very high. All these indicators do not bode well for a fostering a climate of easy and effective start-ups, especially when it comes to long-term survival.

\subsection{Discussion}

The findings in this paper show that a rigid institutional macroeconomic framework discourages greenfield investments. A high level of taxation, a rigid labor market associated with low labor mobility, and higher labor costs act as competitiveness- and growth-constraining factors. Similar findings have been validated by Hunady \& Orviska (2014), who regarding FDI affirm the value of labor market stability with low employee turnover, low labor costs, and transparency of the economy. Unfavorable macroeconomic conditions, e. g. high taxation, high interest rates and high volatility of the financial markets discourage FDI decreasing the economic competitiveness in a finding also pointed out by Yavas \& Malladi (2020). According to their study, the inclusion of capital market variables among FDI determinants is essential to assess the cost of equity and to assess decisions on direct investment and asset allocation. The researchers also noted that the study of FDI has also taken into account too few financial factors that could affect decision-making regarding these investments. Since capital market variables are closely connected to macroeconomic stability, these factors exercise a direct effect on FDI and indirect effect on a country's competitiveness.

This is in line with the results of Franc-Dąbrowska et al. (2019), who show brownfield domination over greenfield since investors favor high, quick and risky revenue earned in the banking and financial sectors to the expense and risk of investment in the rest of the economy.

Furthermore, our results support the thesis of macroeconomic stability to attract FDI, a theory also confirmed in a study by Kokores et al. (2017) which examines the flow of FDI during recession and deflation. Their findings show that deflation does not stop flows of FDI from the Eurozone center to the periphery.

In terms of the relation between FDI and the competitiveness of the economy, macroeconomic stability has shown to be quite relevant, e. g. in Kersan-Škabić (2019), who delineated as statistically significant employment, exports and GDP exogenous as favorable in the short term, but FDI converging towards long-run equilibrium.

Macroeconomic stability is a necessary but not sufficient condition to attract FDI, particularly 
greenfield investments if institutional requirements fall below market standards, as indicated in a study on Greece, Italy, Portugal and Spain (Economou, 2019). These researchers focus their results on the strong and beneficial impact of property rights protection, government transparency, monetary sovereignty and the financial transparency on FDI.

Our study result shows that it is not possible to attract large FDI flows, especially greenfield, without restructuring the whole macroeconomic policy framework.

\section{CONCLUSION}

In the case of the Republic of Croatia, foreign direct investment did not have a significant impact on employment, GDP and exports between 2002 and 2017. As with all developing countries highly similar to Croatia, although the benefits of foreign direct investment are large, such countries do not have enough equity to create more headway. Given that foreign direct investment in a country brings capital assets, modern technology as well as many other positive effects, the situation in the country is getting better. This has not been so obvious in Croatia for the reason stated at the outset. Most investments are not greenfield investments, and the money that comes from investments goes mainly to pay off debt. Nevertheless, developing countries do not use the same technologies and ways of working as developed countries. Likewise, the education and qualifications of workers are not the same, thus neither are the working conditions and processes. A study by Radulescu et al. (2019) supports the thesis that economic growth in the CEE countries is driven mainly by public and personal spending and only to a lesser degree by investment spending.

It has been revealed that foreign direct investment supports domestic development within the country, as investment comes from private and public initiatives from developed countries. Even if the link between economic growth and FDI is weakly exogenous, the lessons learned remain and can apply to other businesses and other countries. It is interesting to note that few previous macroeconomic studies estimate a decline in employment after foreign direct investment, although it is essential to observe that this occurs in the short term.

The Republic of Croatia has so far received a sizeable amount of foreign direct investment funds for a relatively small developing country. Due to many barriers and old debts, Croatia could not make a significant shift based on all these foreign investments. All the advances that have taken place are of little importance compared to what should have been achieved all these years. We have observed no significant changes in the quality of the system nor a major increase in economic growth. What is also worrying is the distribution of FDI across sectors, i. e. the benefits have been clustered in telecommunications and financial services sectors, with other sectors neglected entirely. Many studies have looked at the impact of foreign direct investment on Croatia, with all authors having come to the same conclusion: foreign direct investment in terms of economic growth has not helped Croatia much.

Our study shows that institutional factors and other micro determinants affect the country's competitiveness level beyond the macroeconomic factors investigated here. The study results of Peres et al. (2018) provide empirical evidence that institutional quality has a significant and positive impact on FDI attraction. Following our study results, policymakers in South-Eastern 
Europe should focus on the FDI structure instead of the FDI level, since our study shows FDI in Croatia has not had a significant impact on country's competitiveness.

Our study is limited by the data available on the macro level, with a more significant limitation the bias found within sources of available microdata. Further research studying the determinants of Croatian competitiveness should use data on a microlevel for a detailed exploration of the constraints limiting the nation's competitiveness in the short and long run.

\section{References:}

1. Babić, A., Pufnik, A., \& Stučka, T. (2001). The theory and reality of FDI in the world and in transition countries with special reference to Croatia. Review of Croatian national bank, 9 (1), $1-27$.

2. Belullo, A. (2009). Impact of Foreign Direct Investments on GDP, Employment and Export in (VAR $i$ VECM). Faculty of Economics and Tourism "Dr. Mijo Mirković” Working paper.

3. Belullo, A. (2011). Introduction to Econometrics. Juraj Dobrila University of Pula, Faculty of economics and tourism "Dr. Mijo Mirković", Pula.

4. Bilan, Y., Gavurova, B., Stanislaw, G., \& Tkacova, A. (2017). The Composite Coincident Indicator (CCI) for Business Cycles. Acta Polytechnica Hungarica, 14 (7), 71-90. https://doi.org/10.12700/aph.14.7.2017.7.5

5. Bilan, Y., Vasylieva, T., Lyeonov, S., \& Tiutiunyk, I. (2019). Shadow Economy and its Impact on Demand at the Investment Market of the Country. Entrepreneurial Business and Economics Review, 7 (2), 27-43. https://doi.org/10.15678/EBER.2019.070202

6. Bilas, V., \& Franc, S. (2006). The role of Foreign Direct Investments and the method of incentives, Series of emerging articles. Faculty of Economics Zagreb, 13. http://hrcak.srce.hr/ file/202205

7. Bilas, V. (2006). Attracting Foreign Direct Investments and Competition Across Countries, Faculty of Economics Zagreb conference proceedings, 4 (1), 87-100.

8. Blažková, I., \& Dvouletý, O. (2018). Sectoral and firm-level determinants of profitability: A multilevel approach. International Journal of Entrepreneurial Knowledge, 6 (2), 32-44. https://doi.org/10.2478/IJEK-2018-0012

9. Bobenič Hintošová, A., Bruothová, M., Kubíková, Z., \& Ručinský R. (2018). Determinants of foreign direct investment inflows: A case of the Visegrad countries. Journal of International Studies, 11 (2), 222-235. https://doi.org/10.14254/2071-8330.2018/11-2/15

10. Cieślik, A., \& Hien Tran, G. (2019). Determinants of outward FDI from emerging economies. Equilibrium Quarterly Journal of Economics and Economic Policy, 14 (2), 209-231. https://doi.org/10.24136/eq.2019.010

11. Dritsaki, C., \& Stiakakis, E. (2014). Foreign direct investments, exports, and economic growth in Croatia: A time series analysis. Procedia Economics and Finance, 14, 181-190. https://doi.org/10.1016/S2212-5671(14)00701-1

12. Djordjevic, S., Ivanovic, Z., \& Bogdan, S. (2015). Direct Foreign Investment and the Lack of Positive Effects on the Economy. UTMS Journal of Economics, 6 (2), 197-208. http://hdl.handle.net/10419/146358. 
13. Dobrovič, J., Rajnoha, R., \& Korauš, A. (2018). Effectiveness and performance of tax system in Slovak Republic in terms of its key non-macroeconomics factors. Oeconomia Copernicana, 9 (4), 617-634. https://doi.org/10.24136/oc.2018.030

14. Dvorský, J., Petráková, Z., Ajaz Khan, K., Formánek, I., \& Mikoláš, Z. (2020). Selected aspects of strategic management in the service sector. Journal of Tourism and Services, 20 (11), 109-123. https://doi.org/10.29036/jots.v11i20.146

15. Dvorský, J., Petráková, Z., \& Polách, J. (2019). Assessing the Market, Financial, and Economic Risk Sources by Czech and Slovak SMEs. International Journal of Entrepreneurial Knowledge, 7 (2), 30-40. https://doi.org/10.12345-0008

16. Economou, F. (2019). Economic freedom and asymmetric crisis effects on FDI inflows: The case of four South European economies. Research in International Business and Finance, 49, 114-126. https://doi.org/10.1016/j.ribaf.2019.02.011.

17. Franc-Dąbrowska, J., Mądra-Sawicka, M. \& Ulrichs M. (2019). Determinants of dividend payout decisions - the case of publicly quoted food industry enterprises operating in emerging markets. Economic Research-Ekonomska Istraživanja, 33 (1), 1108-1129. https://doi.org/10.1080/1331677X.2019.1631201

18. Fuller, W. A. (1996). Introduction to Statistical Time Series. New York: John Wiley.

19. Gavurova, B., Kovac, V., Drabik, P., \& Gomory, M. (2019). Exploration of Disparities in Environmental Activities of European Countries from Year 2006 to Year 2016. Acta Montanistica Slovaca, 24 (4), 376-390.

20. Hunady, J., \& Orviska, M. (2014). Determinants of Foreign Direct Investment in EU countries - Do Corporate Taxes Really Matter. Procedia Economics and Finance, 12, 243-250.

21. Jacimovic, D., Dragutinović Mitrović, R., Bjelić, P., Tianping, K., \& Rajkovic, M. (2018). The Role of Chinese Investments in the Bilateral Exports of New EU Member States and Western Balkan Countries. Economic Research-Ekonomska Istrą̌ivanja, 31 (1), 1185-1197. https://doi.org/10.1080/1331677X.2018.1456357

22. Johansen, S. (1991). Estimation and Hypothesis Testing of Cointegration Vectors in Gaussian Vector Autoregressive Models. Econometrica, 59 (6), 1551-1580. https://www.jstor.org/ stable/2938278

23. Johansen, S. (1995). Likelihood-Based Inference in Cointegrated Vector Autoregressive Models. New York: Oxford University Press.

24. Kersan-Škabić, I., \& Zubin, C. (2009). The Influence of Foreign Direct Investment on the Growth of GDP, on Employment and on Export in Croatia. Ekonomski Pregled, 60 (3), 119-151.

25. Kersan-Škabić, I. (2017). Modern Trends in International Economics. Pula, Juraj Dobrila University of Pula.

26. Kersan-Škabić, I. (2019). The drivers of global value chain (GVC) participation in EU member states. Economic Research-Ekonomska Istraživanja, 32 (1), 1204-1218. https://doi.org/10.1080/1331677X.2019.1629978

27. Khan, K., A., Çera, G., \& Nétek, V. (2019). Perception of the Selected Business Environment Aspects by Service Firms. Journal of Tourism and Services, 10 (19), 111-127.

https://doi.org.10.29036/jots.v10i19.115 
28. Klapić, M., \& Nuhanović, A. (2011). Level, Dynamics and Foreign Direct Investment Effects in Developed Countries. Tranzicija, 13 (27), 60-73. https://hrcak.srce.hr/index.php?id_clanak_ jezik $=110846 \&$ show $=$ clanak

29. Kokores, I. T., Kottaridi, C., \& Pantelidis, P. (2017). Intra Eurozone Foreign Direct Investment and Deflation. International Advances in Economic Research, 23, 217-229. https://doi.org/10.1007/s11294-017-9629-9

30. Paun, D. (2019). Tax competition and factors influencing the gross domestic product and foreign direct investments of CEE countries. Economic Research-Ekonomska Istrą̌ivanja, 32 (1), 876-893. https://doi.org/10.1080/1331677X.2019.1585896

31. Pavlović, D. (2008). Foreign Direct Investments in International Trade. Zagreb: Golden marketing.

32. Peres, M., Ameer, W., \& Xu, X. (2018). The impact of institutional quality on foreign direct investment inflows: evidence for developed and developing countries. Economic ResearchEkonomska Istraživanja, 31 (1), 626-644. https://doi.org/ 10.1080/1331677X.2018.1438906

33. Popović, G., \& Erić, O. (2018). Economic development of the Western Balkans and European Union investments. Economic Research-Ekonomska Istrą̌ivanja, 31 (1), 1539-1556. https://doi.org/10.1080/1331677X.2018.1498009

34. Rabar, D., \& Cvek D. (2019). Measuring the macroeconomic performance of the Croatian economy: An empirical efficiency analysis approach. Barković, D., Crnković, B., Zekić Sušac, M., Dernoscheg, K., Pap, N., Runzheimer, B. \& Wentzel, D. (ed.) Interdisciplinary Management Research XV, 1167-1187.

35. Radulescu, M., Serbanescu, L., \& Ileana Sinisi, C. (2019). Consumption vs. Investments for stimulating economic growth and employment in the CEE Countries - a panel analysis. Economic Research-Ekonomska Istraživanja, 32 (1), 2329-2353. https://doi.org/10.1080/1331677X.2019.1642789

36. Škare, M. (2014). Measuring the Correlation Between Business Cycles and Economic Growth in Croatia Using Spectral Analysis. EFZG Occasional Publications (Department of Macroeconomics), in: Scientific conference proceedings: Croatian development potentials, Ed. Družić, G.; Družić, I., Faculty of Economics and Business, University of Zagreb, 1 (3), 53-76.

37. Škare, M. (2001). The Factors of Labour Demand and the Nature of Unemployment in Croatia. Review of social policy, 8 (1), 19-35. https://doi.org/10.3935/rsp.v8i1.227

38. Škuflić, L., \& Botrić, V. (2009). Foreign direct investments in Croatia: regional perspective. Economic research-Ekonomska istraživanja, 22 (3), 9-29. https://hrcak.srce.hr/index.php?id_ clanak_jezik $=73028 \&$ show $=$ clanak

39. Yavas, B. F., \& Malladi, R. K. (2020). Foreign direct investment and financial markets influences: Results from the United States. North American Journal of Economics and Finance, 53, 101-182. https://doi.org/10.1016/j.najef.2020.101182 
Contact information

prof.dr.sc. Marinko Skare

Juraj Dobrila University of Pula

Faculty of Economics and Tourism "Dr. Mijo Mirkovic"

Croatia

E-mail:mskare@unipu.hr

ORCID:0000-0001-6426-3692

Dajana Cvek, mag.oec.

Technical High School Pula

Croatia

E-mail:dajana.cvek@gmail.com

ORCID: 0000-0002-7207-440X 